\title{
Freedom's Law: The Moral Reading of the American Constitution.
}

\author{
By Ronald Dworkin. Cambridge: Harvard University Press, \\ 1996. 389 pp.
}

\section{Reviewed by Jason A. Beyer \\ Loyola University of Chicago}

In Freedom's Law, Ronald Dworkin propounds his theory of constitutional interpretation and applies it to some of the most controversial constitutional issues of the last twenty years, including abortion, affirmative action, pornography, hate speech, gay rights, euthanasia, and free speech. Although each of the chapters of the book was first published as a separate essay, together they provide an engaging and coherent account of Dworkin's constitutional philosophy.

In the first part of the book, Dworkin elaborates and argues for what he calls the moral reading of the Constitution. The United States Constitution, like most contemporary constitutions, defines individual rights in very broad and abstract language. The Fourth Amendment, for example, protects against "unreasonable searches and seizures." The Eighth Amendment protects against "cruel and unusual" punishment. According to the moral reading, clauses that incorporate such terms should be construed as referring to "abstract moral principles and [as] incorporat[ing] these by reference, as limits on government's power." (p. 7).

The moral reading of the Constitution, on Dworkin's view, implies that "government must treat all those subject to its dominion as having equal moral and political status; it must attempt, in good faith, to treat them all with equal concern; and it must respect whatever individual freedoms are indispensable to those ends, including but not limited to the freedoms more specifically designated in the document, such as the freedoms of speech and religion." (p. 8). Since constitutional rights are not limited to those specifically mentioned in the Constitution, constitutional interpretation requires the sort of analysis that is common to applied moral philosophy. On Dworkin's view, then, one cannot resolve a constitutional question about what equal protection requires without resolving the corresponding moral question of what the moral notion of equality requires. In this way, Dworkin's theory "brings political morality into the heart of constitutional law." (p.2)

Unfortunately, Dworkin does not always apply these doctrines consistently in addressing specific legal problems. For example, while the 
moral reading implies that legislative history is of limited importance in interpreting the Constitution, he tends to assign dispositive weight to legislative history when it points in the direction of the result he prefers. In considering the abortion question, Dworkin argues that " $t]$ he key question in the debate over Roe $v$ Wade is not a metaphysical question about whether a fetus has a soul, but a legal question, about the correct interpretation of the Constitution[;] ... [i]t is the question whether the fetus is a constitutional person." (p. 46). If the fetus is constitutional person, then it is protected by the Equal Protection Clause of the Fourteenth Amendment, which declares that no state may deny to any person equal protection of the laws.

Given that Dworkin argues that the language in the Constitution should be construed as having moral content, one would expect him to resolve the issue of whether the fetus is a constitutional person by identifying the moral principles that are incorporated by use of the term 'person'. Thus, one would think that the issue of whether the fetus is a constitutional person, according to the moral reading, turns on whether the fetus is a moral person-and presumably this question would turn on precisely the sorts of metaphysical questions that Dworkin summarily rejects as being irrelevant.

Instead, Dworkin relies on exactly the sort of historical analysis that he finds problematic in Bork's doctrine of original understanding:

The best historical evidence shows, moreover, that even anti-abortion laws, which were not prevalent in the United States before the middle of the nineteenth century, were adopted to protect the health of the mother and the privileges of the medical profession, not out of any recognition of a fetus's rights. Even states that had the most stringent anti-abortion laws before Roe $v$. Wade, moreover, did not punish abortion as severely as murder, as they should have done if they thought a fetus a constitutional person. Nor did they try to outlaw or penalize a woman's procuring an abortion in another state or abroad. (p. 49).

Originalists, of course, typically reach a different conclusion on abortion: they argue that states are free to prohibit or permit abortion as they see fit because there is nothing in the Constitution that protects abortion. Nevertheless, Dworkin's reasoning here is exactly the sort of reasoning that originalism requires. If it were necessary to determine whether the fetus is a constitutional person, the originalist would look at the understanding 
that the public had of the term 'person' at the time the relevant clause was ratified in order to identify its legal meaning. On the question of abortion, then, there is little difference between Dworkin's approach to legal interpretation and that of the originalist. And it is this kind of unevenness that lends credence to the oft-repeated criticism that Dworkin's constitutional theory is result-driven in the sense that the point of his theory is to incorporate his liberal political views into the terms of the Constitution.

Of course, Dworkin would respond that it is not his view that history is irrelevant; indeed, Dworkin argues that " $[t]$ he moral reading asks "judges] to find the best conception of constitutional moral principles ... that fits the broad story of America's historical record." (p. 11). Thus, Dworkin argues that history is relevant, but in a limited sense: "We turn to history to answer the question of what they intended to say, not the different question of what other intentions they had." (p. 10).

But here Dworkin gets himself into exactly the same sort of trouble that plagues many originalists. Bork, for example, argues that Brown v. Board of Education was correctly decided, even though it is clear that, at the time the Fourteenth Amendment was ratified, no one understood or intended that its terms would prohibit school segregation. Dworkin can't resist the temptation:

The Court's decision [in Brown] was plainly required by the moral reading, because it is obvious now that official school segregation is not consistent with equal status and equal concern for all races. But the originalist strategy, consistently applied, would have demanded the opposite conclusion, because, as I said, the authors of the equal protection clause did not believe that school segregation, which they practiced themselves, was a denial of equal status, and did not expect that it would one day be deemed to be so. The moral reading insists that they misunderstood the moral principle that they themselves enacted into law. The originalist strategy would translate that mistake into enduring constitutional law. (p. 13).

An anti-abortionist who endorses Dworkin's constitutional theory could make exactly the same criticism of Dworkin's analysis of abortion: it does not matter what legislatures enacted in the nineteenth century with respect to the question of abortion; for they misunderstood the moral principle that was enacted into law by the Fourteenth Amendment. Thus, an anti-abortionist could argue that the moral reading, consistently applied, 
requires that the Constitution be interpreted as giving protection to fetuses.

What Dworkin's theory needs, but does not provide, is some kind of principle or approach for determining when the history should be discounted because it is mistaken. Without that account, his theory is vulnerable to the criticism that has been directed at all non-originalist approaches. Critics of such approaches commonly complain that they are inconsistent with democratic ideals inasmuch as they allow unelected judges to impose their subjective moral convictions on the public as law. While Dworkin rejects the idea that the moral reading allows judges to read their convictions into law, his analyses of Brown and Roe suggest that he has not,. fully appreciated the force of the criticism. The most interesting and controversial constitutional issues are difficult because they can be coherently decided in more than one way. Historical and political/moral considerations often pull in conflicting directions, making it possible for a judge to arrive at conflicting decisions. If the judge weighs the history more heavily than the conflicting political considerations, the decision goes one way; if she weighs the political considerations more heavily than the conflicting history, the decision goes the other way. Non-originalist approaches get into trouble because they do not provide any viable way of constraining the judge's decision as to how to weigh history and political morality relative to each other, which leaves the judge free to weigh them in accordance with her moral convictions with respect to how the case should turn out. As Dworkin's analysis of Brown and Roe indicates, the moral reading has the same sort of difficulties here as other forms of non-originalism.

More successful is Dworkin's criticism of Borkean originalism. Bork rejects the idea that his originalist theory of constitutional interpretation implies that Brow'n was incorrectly decided. On Bork's view, the original intention that counts is not a set of particular opinions the framers might have had about whether the Fourteenth Amendment prohibits school segregation. Rather it is a set of opinions about which general principle was promulgated by the Fourteenth Amendment. What the Fourteenth Amendment ratified into law was a general principle about equality that, according to Bork, is inconsistent with school segregation. Thus, Bork attempts to conclude from an originalist perspective that Brown was correctly decided.

But, as Dworkin points out, Bork's substantive analysis of Supreme Court decisions often relies on claims about particular opinions the framers had about concrete cases, rather than any general opinions they might have had about principles. For example, Bork endorses the Court's narrowly historical analysis in Bowers v. Hardwick, in which the Court held 
that the state could prohibit same-sex sexual acts. The Court reached its decision in Bowers principally on the strength of the claim that prohibitions against same-sex sexual behavior were common at the time the relevant constitutional provisions were ratified. But this kind of analysis makes sense only if it is the framers' particular opinions about concrete cases that count, and not opinions about matters of general principle. Accordingly, Dworkin argues that Bork is confronted with a dilemma:

An appeal to the framers' intention ... decides nothing until some choice is made about the right way to formulate that intention on any particular issue. If we choose the narrowest, most concrete formulation of original intention, which fixes on the discrete expressed opinions of the framers and ignores the more general moral vision they were trying to serve, then we must regard Brown as unfaithful to the framers' will; and the conclusion will seem to most people ample evidence that the most concrete formulation is the wrong one. If we assign to the framers a principle that is sufficiently general not to seem arbitrary and ad hoc, on the other hand, like the principle that government must not discriminate on grounds of prejudice, then many of the decisions Bork castigates as illegitimate become proper according to the standards Bork himself claims to endorse. (p. 271).

But even in what is perhaps the most successful part of the book, Dworkin's criticism can be turned around and directed at the moral reading; the argument would run as follows. An appeal to reconciling history and political morality decides nothing until some choice is made about the right way to weigh the competing claims of history and political morality. If we choose to assign more weight to history, then we must regard Brown as incorrectly decided; and the conclusion will seem to most people ample evidence that the choice of history as the more important value is the wrong one. If we choose to assign more weight to political morality, then many of the decisions that Dworkin accepts as legitimate, such as the Court's protection of abortion rights on the strength of historical considerations, become open to question. It is indicative of the problems Dworkin's theory faces that they seem to dog him even in his successful criticisms of other theories.

Nevertheless, there is much to be learned from the book. While Dworkin's theory, like every other theory of constitutional adjudication, 
is vulnerable to serious criticisms, it represents an important contribution to philosophy of law-and one that deserves careful study by lawyers, judges and philosophers. His novel argument that Bork lacks a coherent constitutional theory is as entertaining as it is persuasive. As for particular issues of law, Dworkin's analysis is, as always, clear, forceful, and elegant. His penetrating analysis of the Supreme Court's treatment of issues involving euthanasia, free speech, and academic freedom, as well as his spirited dialogue with Catharine MacKinnon on the question of pornography, make Freedom's Law an engaging and enlightening read. 